\title{
ANALISIS FAKTOR YANG BERPENGARUH TERHADAP KUALITAS JIWA KEWIRAUSAHAAN PERAJIN STAGEN INOVASI
}

\author{
Dian Retnaningdiah ${ }^{1)}$ \\ Djandjang Purwo Sedjati ${ }^{2)}$ \\ Titiana Irawani ${ }^{3)}$ \\ ${ }^{1)}$ Fakultas Ekonomi, Universitas Widya Mataram Yogyakarta \\ e-mail: dian_rdh@yahoo.co.id \\ ${ }^{2)}$ Fakultas Seni Rupa, Institut Seni Indonesia Yogyakarta \\ e-mail: mrs.djandjang@gmail.com \\ 3) Fakultas Seni Rupa, Institut Seni Indonesia Yogyakarta \\ e-mail: titiana.irawani@yahoo.com
}

The aim of this research is want to know the effect of creativity and innovation of the entrepreneurship's quality. The survey methode has been used in this research. The sample number used is 30 respondents from the small medium entrepreneurs with the purposive random sampling technique. The data analysis uses reliability and validity for measuring the questionares. The regression analysis is used as well. By using 5\% level of significant, the results show that in partially and simultaneously both creativity and innovation are shown affecting the entrepreneurship's quality.

Keywords: small medium enterprises, entrepreneurship, innovation, creativity, stagen

\section{PENDAHULUAN}

Bantul sebagai salah satu daerah wisata di Yogyakarta, menyimpan beberapa potensi, diantaranya sebagai tempat wisata pantai, daerah penghasil gerabah dan juga sebagai daerah penghasil stagen. Daerah penghasil stagen di wilayah ini adalah desa Argosari. Stagen dikenal sebagai pengikat kain yang biasa dikenakan berpasangan dengan kebaya. Sedangkan stagen inovasi adalah produk-produk yang dihasilkan dari bahan dasar stagen yang memiliki bentuk, fungsi, serta nilai tambah tertentu. Stagen yang semula berbentuk panjang dengan ukuran lebar $15 \mathrm{~cm}$ dan beberapa variasi ukuran panjang $5 \mathrm{~m}, 8 \mathrm{~m}$ atau $10 \mathrm{~m}$ hanya berfungsi sebagai pengikat kain diubah bentuk dan fungsi lain, tanpa menghilangkan ciri khusus dari bentuk asli stagennya terutama ukuran lebar stagen. Stagen diubah bentuk dan fungsi menjadi antara lain tas, taplak meja, sekat ruang, tempat koran/majalah, dompet, dan sarung bantal. Produk ini dikembangkan di samping memiliki nilai seni yang tinggi, juga dapat membuka lapangan pekerjaan baru dan meningkatkan nilai ekonomi perajin. Dengan demikian harapan akan terjadi peningkatan kesejahteraan individu, kesejahteraan masyarakat dan menjadi kesejahteraan wilayah, khususnya di Desa Argosari akan dapat terwujud.

Usaha yang belum lama dikembangkan ini akan menghadapi berbagai tantangan sebagaimana dihadapi para UMKM pada umumnya. Terlebih dalam waktu dekat dengan hadirnya MEA, akan terjadi persaingan ketat baik produk maupun sumberdaya manusianya. Muncul tuntutan untuk terus menerus membenahi diri, meningkatkan kualitas layanan agar tak sekedar dapat beradaptasi, namun harus dapat pula mengantisipasi setiap perubahan pasar dan memberikan solusi terhadap kebutuhan-kebutuhan (Sutarta, 2005). Hal ini bermakna bahwa kebutuhan konsumen akan kualitas produk dan layanan menjadi prioritas. Harus ada pemikiran untuk selalu mengembangkan dan meningkatkan 
mutu desain produk. Kondisi ini menuntut adanya peningkatan kualitas sumberdaya manusianya, dalam hal ini perajin untuk memiliki kreativitas dan kemampuan inovasi yang tinggi.

Penelitian ini bertujuan untuk mengetahui kualitas jiwa kewirausahaan perajin stagen inovasidi Desa Argosari dilihat dari aspek sikap kreativitas dan inovatif yang mereka miliki, sehubungan dengan berbagai kendala yang dihadapi. Dengan diketahuinya kualitas jiwa kewirausahaan, maka diharapkan akan mempermudah bagi pihak terkait dalam memberikan program pemberdayaan bagi perajin stagen inovasi. Penelitian ini diharapkan dapat memberikan masukan melalui program pemberdayaan yang efisien dan tepat sasaran, yang mengarah pada kebutuhan perajin stagen inovasi khususnya di Desa Argosari.

\section{KAJIAN TEORI}

\section{Kewirausahaan dan Kualitas Jiwa Kewirausahaan}

Kewirausahaan merupakan tanggapan terhadap peluang usaha yang terungkap dalam seperangkat tindakan serta membuahkan hasil berupa organisasi usaha yang melembaga, produktif, dan inovatif. Zimmerer dan Scarborough (2008) mengemukkan kewirausahaan merupakan hasil dari proses disiplin dan sistematis dalam menerapkan kreativitas dan inovasi terhadap kebutuhan peluang di pasar. Seorang wirausaha adalah orang yang melihat adanya peluang kemudian menciptakan sebuah organisasi untuk memanfaatkan peluang tersebut (Unggul, 2009). Lebih jauh dijelaskan bahwa wirausaha adalah orang yang mempunyai kemampuan melihat dan menilai kesempatan bisnis, mengumpulkan sumber daya yang dibutuhkan guna mengambil keuntungan dan tindakan yang cepat dalam memastikan kesuksesan. Dalam menjalankan tugas kewirausahaannya, wirausahawan perlu memperhatikan faktor-faktor yang nantinya akan dapat mendukung keberhasilannya maupun faktor-faktor yang dapat menyebabkan kegagalan (Unggul, 2008). Keberhasilan dalam berwirausaha diperlukan dukungan dari orang lain yang berhubungan dengan bisnis yang kita kelola. Seorang wirausaha harus mau menghadapi tantangan dan risiko yang ada. Risiko dijadikan sebagai pemacu untuk maju. Dengan adanya risiko, seorang wirausaha akan semakin maju.

Kualitas jiwa kewirausahaan seseorang dapat dilihat ketika dihadapkan pada sejumlah permasalahan yang dapat mempengaruhi semangat dalam menjalankan tugas kewirausahaannya. Permasalahan tersebut merupakan kelemahan-kelemahan dalam berwirausaha, yaitu tingkat risiko kegagalan tinggi sementara tingkat pendapatan yang tidak pasti, stres yang tinggi, cepat putus asa, dan tanggungjawab penuh yang harus tetap diemban.

Kualitas jiwa kewirausahaan merupakan suatu standar jaminan terbaik untuk menjadi wirausaha yang mampu memenuhi kebutuhan, mengambil risiko, memanfaatkan peluang bisnis, inovatif, percaya diri, dan kemauan melakukan kegiatan bisnis yang kuat sehingga wirausaha tersebut mampu mempertahankan kekuatan dalam mengahadapi persaingan, mampu menciptakan pertumbuhan keuntungan yang tinggi, dan terjaminnya kelangsungan hidup (Mahrinasari, 2003). Kualitas jiwa pencarian peluang dan inovatif, kegigihan dan ketekunan, ketaatan pada kontak kerja, tuntutan terhadap kualitas kerja dan efisiensi, pengambilan risiko, penetapan tujuan, pencarian informasi, perencanaan yang sistematis dan monitoring, persuasi dan penciptaan jaringan kerja, kepercayaan diri, inovasi, dan pengetahuan. 
Yuniarto (2004) menyatakan bahwa dalam kewirausahaan, nilai-nilai penting yang harus dimiliki adalah dalam hal kreativitas dan inovasi. Kreativitas dan inovasi guna menciptakan nilai tambah untuk meraih keunggulan, yang tercipta melalui pengembangan pengetahuan, keterampilan dan kemampuan. Kreativitas dan inovasi akan membantu dalam upaya untuk memiliki daya tawar yang kuat dalam menghadapi persaingan (Suryana, 2003). Lebih jauh Zimmerer dan Scarborough (2008) mengemukakan bahwa kreativitas dan inovasi sering menjadi jantung bagi kemampuan perusahaan kecil untuk dapat bersaing dengan pesaing yang lebih besar. Keunggulan bersaing bagi perusahaan kecil dapat tercipta melalui berpikir dan sikap yang lebih kreatif dan inovatif.Dua nilai wirausaha (kewirausahaan) yang utama adalah kreativitas dan inovasi (Yuniarto, 2004). Kreativitas (creativity) adalah kemampuan untuk mengembangkan ide-ide baru dan menemukan cara-cara baru dalam memandang masalah dan kesempatan. Sedangkan inovasi (innovation) adalah kemampuan untuk mengaplikasikan pemecahan yang kreatif atas masalah dan kesempatan yang dihadapi untuk meningkatkan kualitas kehidupan orang. Kreativitas menurut Theodore Levitt adalah memikirkan sesuatu yang baru (thingking new things), sedangkan inovasi adalah melakukan sesuatu yang baru (doing new things). Dengan kata lain wirausahawan yang sukses akan memikirkan dan melakukan sesuatu yang baru atau sesuatu yang lama dengan cara baru.

\section{Kreativitas}

Kreativitas (creativity) adalah kemampuan untuk mengembangkan ide-ide baru dan untuk menemukan cara-cara baru dalam melihat masalah dan peluang (Yudiarto, 2004). Kreativitas bisa ditumbuhkan dari wirausahawan yang tidak kreatif menjadi kreatif ataupun dari wirausahawan yang sudah kreatif menjadi lebih kreatif. Beberapa cara yang dapat membantu dalam mendukung kreativitas adalah (Zimmerer dan Scarborough 2008): meningkatkan kreativitas organisasi, dengan melakukan hal-hal sebagai berikut: memasukkan kreativitas sebagai nilai inti perusahaan, merangkul keragaman, mengharapkan kreativitas, mengharapkan dan memberi ruang pada kegagalan, mendorong rasa ingin tahu, melakukan perubahan tata ruangan secara periodik, memandang masalah sebagai tantangan, memberikan pelatihan kreativitas, memberikan dukungan, mengembangkan prosedur untuk menangkap ide-ide, berbicara dengan pelanggan, mencari tahu kegunaan produk atau jasa perusahaan, memberi penghargaan atas kreativitas, memberi contoh perilaku kreatif. Meningkatkan kreativitas individual dapat dilakukan dengan: memberi kesempatan pada diri sendiri menjadi kreatif, memberi pikiran dengan masukan segar setiap hari, mengamati berbagai produk dan jasa perusahaan lain, terutama yang berada dalam pasar yang berbeda, menyadari kekuatan kreatif dari kesalahan, selalu membawa buku harian untuk mencatat pikiran dan ide yang ada dalam diri kita, dan mendengarkan orang lain.

Berpikir kreatif adalah inti keterampilan bisnis dan wirausahawan menjadi pemimpin dalam usaha mengembangkan dan menerapkan keterampilan tersebut. Dalam perekonomian global yang menjadikan munculnya berbagai macam persaingan ketat, kreativitas sangat penting untuk mengembangkan keunggulan bersaing dan merupakan kebutuhan untuk keberlangsungan hidup. Wirausahawan harus berani mengubah perspektif mereka dalam melihat dunia dengan cara-cara baru yang berbeda. 


\section{Inovasi}

Inovasi (innovation) adalah kemampuan untuk menerapkan solusi kreatif terhadap masalah dan peluang untuk meningkatkan atau untuk memperkaya kehidupan orangorang. Inovasi merupakan instrumen khusus wirausahawan, sarana yang mereka gunakan untuk mengeksploitasi perubahan peluang untuk bisnis atau jasa yang berbeda (Zimmerer dan Scarboroug, 2008). Inovasi harus menjadi proses yang konstan, karena apabila seorang wirausahawan terlalu banyak ide tidak akan sukses dan bisa mengarah pada kegagalan inovasi. Dengan demikian dapat kita katakan bahwa wirausahawan yang sukses adalah mereka yang memiliki ide dan kemudian mencari cara agar ide tersebut sukses memecahkan masalah atau memuaskan kebutuhan. Inovasi dapat melalui melakukan sesuatu dari nol, akan tetapi memiliki kecenderungan merupakan hasil usaha mengelaborasi dari hal-hal sudah ada, dari usaha menggabungkan hal-hal yang lama dengan cara-cara baru, ataupun dari mengambil sesuatu yang lebih sederhana atau lebih baik. Inovasi dapat diperoleh melalui tahapan (Affandi, 2011): 1) inovasi untuk bertahan hidup, 2) inovasi untuk meningkatkan daya kompetisi, dan 3) inovasi sebagai aset nasional (inovasi sebaiknya sudah dipatenkan). Inovasi adalah salah satu kunci utama yang mengarah pada keunggulan kompetitif. Oleh karena itu inovasi dan hubungannya dengan sumberdaya dan kemampuan organisasi memerlukan penelitian lebih lanjut (Hadjimolis, 2000).

\section{Penelitian Terdahulu}

Penelitian Anggraini, dkk (2007) tentang wanita nelayan sebagai pelaku usaha menyebutkan bahwa program pemberdayaan wanita nelayan masih ditemukannya beberapa persoalan seperti, program berjalan belum optimal yang ditandai dengan antara lain kurangnya keterampilan dalam inovasi produk dan manajemen kelompok sebagai akibat dari minimnya pendamping. Permasalahan ini nampaknya memiliki beberapa kesamaan dengan pelaku usaha kecil lainnya.

Penelitian Yuniarto (2002) tentang penilaian kebutuhan keterampilan dan kemampuan pemasaran pada Usaha Kecil Sektor Industri di Kabupaten Sleman, dengan exploratory field research menunjukkan bahwa keterampilan dan kemampuan yang dibutuhkan oleh usaha kecil sektor industri tersebut antara lain adalah keterampilan dan kemampuan dalam mencari potensi usaha lain yang lebih prospektif, dalam hal membentuk dan mengelola asosiasi pemasaran, kemampuan dan keterampilan dalam mengembangkan produk yang siap bersaing di pasar internasional.

Penelitian Mahrinasari (2003) memberikan hasil baik secara parsial maupun bersamasama bahwa jiwa kewirausahaan dipengaruhi secara positif oleh faktor pencarian peluang, kegigihan, dan ketekunan, tuntutan terhadap kualitas dan efisiensi hasil, pengambilan risiko, penetapan tujuan, ketaatan kontrak kerja, pencarian informasi, perencanaan sistematis dan monitoring, persuasi dan penyusunan jaringan usaha, kepercayaan diri, inovasi dan pengetahuan.

Penelitian Anggraini, dkk. (2007) tentang kajian evaluatif restrospektif prospektif pemberdayaan wanita nelayan dengan mengoptimalkan swamitra mina integratif program PEMP di DIY, hasil menunjukkan bahwa wanita nelayan yang merupakan pelaku usaha kecil, memiliki keterbatasan keterampilan dalam inovasi produk usaha dan manajemen kelompok. Hal ini dikarenakan program pemberdayaan yang belum optimal, kurangnya pelatihan dan pendampingan. 


\section{Hipotesis}

Berdasar uraian tersebut hipotesis dalam penelitian ini dirumuskan sebagai berikut:

H1: Secara parsial kreativitas berpengaruh terhadap kualitas jiwa kewirausahaan perajin stagen inovasi

$\mathrm{H} 2$ : Secara parsial inovasi berpengaruh terhadap kualitas jiwa kewirausahaan perajin stagen inovasi

H3: Secara simultan kreativitas dan inovasi berpengaruh terhadap kualitas jiwa kewirausahaan perajin stagen inovasi

\section{METODE PENELITIAN}

Populasi dalam penelitian ini adalah wanita di Desa Argosari yang mempunyai keahlian dalam bidang menjahit. Pengambilan sampel menggunakan metode purposive random sampling, dengan kriteria wanita berusia 16 sampai dengan 50 tahun. Diperoleh sebanyak 30 orang yang memenuhi syarat untuk diambil sebagai sampel.

Penelitian ini menggunakan sumber data primer dan data sekunder. Data primer dikumpulkan melalui kuesioner dan teknik wawancara secara langsung dari kelompok sasaran yang berupa jawaban atas pertanyaan yang diajukan dalam kuesioner mengenai kreativitas dan inovasi dalam pengembangan usaha. Data sekunder diperoleh dari dokumen-dokumen berupa buku, jurnal, surat kabar dan sejenisnya.

Penelitian ini menggunakan variabel 1) kualitas jiwa kewirausahaan, 2) kreativitas, dan 3) inovasi. Kualitas jiwa kewirausahaan dan kreativitas merupakan variabel bebas (independent), sedangkan inovasi merupakan variabel terikat (dependent). Indikator kualitas jiwa kewirausahaan adalah adanya suatu standar jaminan terbaik untuk menjadi wirausaha yang mampu memenuhi kebutuhan, mengambil risiko, dan memanfaatkan peluang bisnis, inovatif, percaya diri, dan berkemauan melakukan kegiatan bisnis yang kuat sehingga wirausaha tersebut mampu mempertahankan kekuatan dalam menghadapi persaingan, mampu menciptakan pertumbuhan keuntungan yang tinggi, dan kelangsungan hidup usaha terjamin (Mahrinasari, 2003). Indikator kreativitas adalah adanya kemampuan untuk mengembangkan ide baru dan menemukan cara-cara baru dalam memandang masalah dan kesempatan (Yuniarto, 2004). Indikator inovasi adalah kemampuan untuk mengaplikasikan pemecahan yang kreatif atas masalah dan kesempatan yang dihadapi untuk meningkatkan kualitas hidup orang (Yuniarto, 2004). Butir-butir dari instrumen variabel akan diukur dengan lima skala likert.

\section{Model Penelitian}

Model hubungan kreativitas dan inovasi dapat digambarkan sebagai berikut:

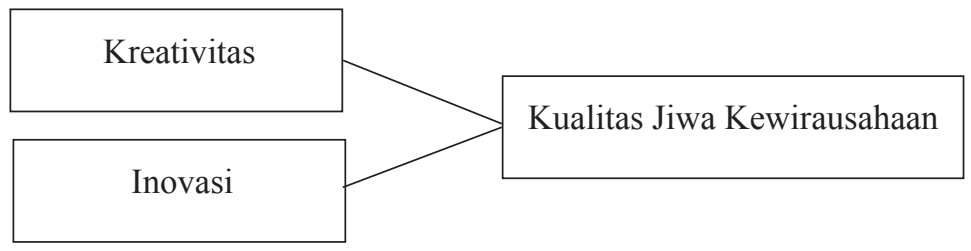

\section{Uji Reliabilitas dan Validitas}

Uji reliabilitas untuk menunjukkan sejauh mana suatu hasil pengukuran relatif konsisten apabila pengukuran diulangi dua kali atau lebih. Uji reliabilitas atas setiap 
butir pertanyaan angket dilakukan dengan menggunakan uji statistik Cronbach Alpha ( $\alpha$ ) karena butir pertanyaan menggunakan metode pengukuran skala. Perumusan menurut $\operatorname{Umar}(2000): \alpha$

$$
r_{11}=\left[\left(\frac{k}{k-1}\right)\left(1-\frac{\sum \sigma_{b}^{2}}{\sigma_{t}^{2}}\right)\right]
$$

Keterangan:

$r_{11} \quad=$ Reliabilitas instrumen

$k^{11} \quad=$ Banyak jumlah pertanyaan

$\sigma^{2} \quad=$ Varian total

$\Sigma \sigma_{\mathrm{b}}^{2}=$ Jumlah varian butir

Pengukuran reliabilitas dengan cara one shot atau pengukuran satu kali saja digunakan dalam penelitian ini. Kemudian hasilnya dibandingkan pertanyaan lain dengan atau mengukur korelasi antar jawaban pertanyaan. Nunnally (1960) menyebutkan bahwa suatu konstruk atau variabel dikatakan reliabel jika memberikan nilai Cronbach Alpha ( $\sigma$ ) $>0.60$ (Ghozali, 2009)

Uji validitas digunakan untuk mengukur sah atau valid tidaknya suatu kuesioner. Suatu kuesioner dikatakan valid jika pertanyaan pada kuesioner mampu untuk mengungkapkan sesuatu yang akan diukur oleh kuesioner tersebut (Ghozali, 2009). Ukuran validitas dalam penelitian ini dilakukan dengan korelasi antar skor butir pertanyaan dengan total skor konstruk atau variabel. Koefisien korelasi dihitung dengan menggunakan metode product moment dengan rumus (Umar, 2000):

$$
\mathrm{r}_{\mathrm{xy}}=\frac{n\left(\sum_{x y}\right)-\left(\sum_{x \sum_{y}}\right)}{\sqrt{\left[n \sum x^{2}-\left(\sum x\right)^{2}\right]\left[n \sum y^{2}-\left(\sum y\right)^{2}\right]}}
$$

Keterangan:

$\mathrm{r}_{\mathrm{xy}} \quad=$ koefisien korelasi antara skor butir (x) dengan skor variabel (y)

$\mathrm{n} \quad=$ jumlah responden yang diuji coba

$\Sigma \mathrm{x} \quad=$ jumlah skor butir

$\Sigma \mathrm{y} \quad=$ jumlah skor variabel

$\Sigma \mathrm{x}^{2} \quad$ jumlah skor butir (x) kuadrat

Uji signifikansi validitas dilakukan dengan membandingkan nilai $r$ hitung dengan $r$ tabel untuk degree of freedom $(\mathrm{df})=\mathrm{n}-2$, $\mathrm{n}$ menunjukkan jumlah sampel. Jika $\mathrm{r}$ hitung lebih besar dari $r$ tabel dan nilai positif maka butir pertanyaan atau indikator dinyatakan valid.

\section{Uji Asumsi Klasik}

Sebelum melakukan pengujian hipotesis, terlebih dahulu akan dilakukan pengujian terhadap penyimpangan terhadap asumsi klasik, yaitu uji normalitas dengan menggunakan 
teknik kolmogorov smirnov, uji heteroskedastisitas, multikolinieritas, dan autokorelasi agar uji regresi memberikan hasil yang tidak bias.

1. Uji normalitas, bertujuan untuk menguji apakah dalam model regresi variabel pengganggu atau residual memiliki distribusi normal. Menguji normalitas data dengan menggunakan one-sample Kolmogorov-Smirnov test (Ghozali, 2009). Jika Asymp Sig (2-tailed) > 0.05 data berdistribusi tidak normal, dan sebaliknya.

2. Uji heteroskedastisitas, bertujuan untuk menguji apakah dalam model regresi terjadi ketidaksamaan variance dari residual satu pengamatan ke pengamatan lainnya. Model regresi yang baik adalah yang homoskesdastisitas, yakni variance dari residual satu pengamatan ke pengamatan lain bersifat tetap (Ghozali, 2009).

3. Uji multikolinieritas, bertujuan untuk menguji apakah model regresi ditemukan adanya korelasi antar variabel bebas (independen). Jika ditemukan adanya multikolinieritas, maka koefisien regresi variabel tidak tentu dan kesalahan menjadi tidak terhingga (Ghozali, 2009). Salah satu metode untuk mendiagnosa adanya multikolinieritas adalah dengan menganalisis nilai tolerance dan lawannya variance inflation factor (VIF). Tolerance mengukur variabilitas variabel independen yang terpilih yang tidak dijelaskan oleh variabel independen lainnya. Nilai tolerance yang rendah sama dengan nilai VIF tinggi, karena VIF $=1 /$ Tolerance. Nilai cut off yang dipakai untuk menunjukkan adanya multikolinearitas adalah nilai tolerance kurang dari 0,1 atau sama dengan nilai VIF lebih dari 10 (Ghozali, 2009 ).

\section{Analisis Regresi Berganda}

Analisis ini digunakan untuk membuktikan kebenaran hipotesis yang diajukan. Setelah dilakukan uji asumsi klasik dan dinyatakan data normal, tidak terdapat heteroskedastisitas, multikolonieritasdan autokorelasi, maka dilakukan pengujian hipotesis dengan menggunakan.persamaan regresi berganda sebagai berikut:

$$
\mathrm{Y}=\mathrm{a}+\mathrm{b}_{1} \mathrm{X}_{1}+\mathrm{b}_{2} \mathrm{X}_{2}+\mathrm{e}
$$

Keterangan :

$\mathrm{Y} \quad$ : Variabel dependent/kualitas jiwa kewirausahaan

$\mathrm{X}_{1} \quad$ : Variabel independen/kreativitas

$\mathrm{X}_{2} \quad$ : Variabel independen/inovasi

a : Konstanta

$\mathrm{b}_{1}, \mathrm{~b}_{2}$ : Koefisien regresi

e : Variabel pengganggu

\section{Uji Regresi Berganda}

Dalam penelitian ini uji regresi berganda akan digunakan untuk menguji hipotesishipotesis yang diajukan, meliputi uji t dan uji F. Uji t digunakan untuk menguji koefisien regresi secara parsial yang besarnya nilai thitung dapat ditentukan dengan rumus sebagai berikut:

$$
t=\frac{r \sqrt{n-2}}{1-r^{2}}
$$

Dengan menggunakan taraf signifikansi $5 \%$ dan dilihat dari nilai signifkansinya, maka nilai tersebut dibandingkan dengan taraf signifikansi yang digunakan. $\mathrm{H}_{\mathrm{o}}$ akan ditolak apabila nilai signifikansi $<5 \%$ dan $\mathrm{H}_{\mathrm{o}}$ diterima apabila nilai signifikansi $>5 \%$. 
Uji $\mathrm{F}$ digunakan untuk menguji koefisien regresi secara serempak yang besarnya nilai $\mathrm{F}$ hitung dapat ditentukan dengan rumus sebagai berikut:

$$
\mathrm{F}_{\text {hitung }}=\frac{\mathrm{Jk} \text { (regresi) } / \mathrm{k}}{\mathrm{Jk}(\text { Standar Error }) /(\mathrm{n}-\mathrm{k}-1)}
$$

Keterangan:

$\mathrm{k}=$ variabel penelitian

$\mathrm{n}=$ jumlah data

Dengan taraf signifikansi 5\%, dan dilihat dari nilai signifkansinya, maka nilai tersebut dibandingkan dengan taraf signifikansi yang digunakan. $\mathrm{H}_{\mathrm{o}}$ akan ditolak apabila nilai signifikansi $<5 \%$ dan $\mathrm{H}_{\mathrm{o}}$ diterima apabila nilai signifikansi $>5 \%$.

\section{HASIL DAN PEMBAHASAN}

\section{Pengujian Reliabilitas dan Validitas}

Uji reliabilitas dan validitas dilakukan untuk mengetahui keakuratan alat ukur dan hubungan masing-masing variabel yang diteliti pada faktor kualitas jiwa kewirausahaan. Uji reliabilitas untuk variabel kualitas jiwa kewirausahaan, kreativitas, dan inovasi dapat dilihat pada Tabel 1.

Tabel 1. Hasil Pengujian Reliabilitas

\begin{tabular}{clcc}
\hline No & \multicolumn{1}{c}{ Variabel } & $\begin{array}{c}\text { Cronbach's Alpha Based on } \\
\text { Standardized Items }\end{array}$ & Keterangan \\
\hline 1. & Kualitas jiwa kewiraushaan (KWU) & 0.900 & reliabel \\
2. & Kreativitas & 0.780 & reliabel \\
3. & Inovasi & 0.865 & reliabel \\
\hline
\end{tabular}

Tabel 1 memperlihatkan bahwa ketiga variabel adalah reliabel karena mempunyai nilai Cronbach's Alpha $>0.60$ atau 60\% menurut kriteria Nunnally (1960). Variabel kualitas jiwa kewirausahaan mempunyai nilai Cronbach's Alpha sebesar 90\%, kreativitas $78 \%$, dan Inovasi $86,5 \%$.

Uji validitas dalam penelitian ini dilakukan korelasi antar skor butir pertanyaan dengan total skor konstruk atau variabel (Ghozali, 2009). Uji signifikansi dilakukan dengan membandingkan nilai $r$ hitung dengan $r$ tabel untuk degree of freedom $(d f)=n-2$, dalam hal ini $\mathrm{n}$ adalah jumlah sampel. Penelitian ini hasil yang diperoleh menunjukkan bahwa besarnya df dapat dihitung 30-2 $=28$ dan alpha 0.05, diperoleh $\mathrm{r}$ tabel $=0.361$ (dapat dilihat pada $\mathrm{r}$ tabel pada $\mathrm{df}=28$ dengan uji dua sisi). Nilai $\mathrm{r}$ hitung dapat dilihat pada kolom Corrected Item-Total Correlation. Jika $r$ hitung $>\mathrm{r}$ tabel dan nilai positif, maka butir atau pertanyaan atau indikator dinyatakan valid.

Tabel 2 menunjukkan nilai $\mathrm{r}$ hitung pada variabel kualitas jiwa kewirausahaan, kreativitas, dan inovasi. 
Tabel 2. Hasil Pengujian Validitas

\begin{tabular}{|c|c|c|c|}
\hline No & Butir Pertanyaan & Corrected Item-Total Correlation & Keterangan \\
\hline 1. & KWU_1 & .657 & valid \\
\hline 2. & KWU_2 & .631 & valid \\
\hline 3. & KWU_3 & .813 & valid \\
\hline 4. & KWU_4 & .717 & valid \\
\hline 5. & KWU_5 & .631 & valid \\
\hline 6. & KWU_6 & .799 & valid \\
\hline 7. & KWU_7 & .570 & valid \\
\hline 8. & KWU_8 & .526 & valid \\
\hline 9. & KWU_9 & .652 & valid \\
\hline 10. & kreativitas_1 & .695 & valid \\
\hline 11. & kreativitas_2 & .505 & valid \\
\hline 12. & kreativitas_3 & .523 & valid \\
\hline 13. & kreativitas_4 & .497 & valid \\
\hline 14. & kreativitas_5 & .664 & valid \\
\hline 15. & kreativitas_6 & .566 & valid \\
\hline 16. & kreativitas_7 & .409 & valid \\
\hline 17. & Inovasi_1 & .763 & valid \\
\hline 18. & Inovasi_2 & .519 & valid \\
\hline 19. & Inovasi_3 & .597 & valid \\
\hline 20. & Inovasi_4 & .448 & valid \\
\hline 21. & Inovasi_5 & .587 & valid \\
\hline 22. & Inovasi_6 & .382 & valid \\
\hline 23. & Inovasi_7 & .489 & valid \\
\hline 24. & Inovasi_8 & .614 & valid \\
\hline 25. & Inovasi_9 & .700 & valid \\
\hline 26. & Inovasi_10 & .688 & valid \\
\hline
\end{tabular}

Tabel 2 menunjukkan bahwa nilai $\mathrm{r}$ hitung (pada kolom Corrected Item-Total Correlation) lebih besar $(>)$ dan positif dibandingkan dengan $\mathrm{r}$ tabel yang nilainya sebesar 0.361 . Dengan demikian dapat dikatakan bahwa semua butir pertanyaan yang ada dinyatakan valid.

\section{Pengujian Hipotesis}

Setelah dilakukan uji asumsi klasik variabel penelitian ini dinyatakan terbebas dari normalitas, autokorelasi, multikolinieritas, dan heteroskedastisitas. Untuk selanjutnya analisis regresi dilakukan untuk menguji hipotesis penelitian. Adapun model persamaan regresi yang terbentuk setelah olah data adalah sebagai berikut:

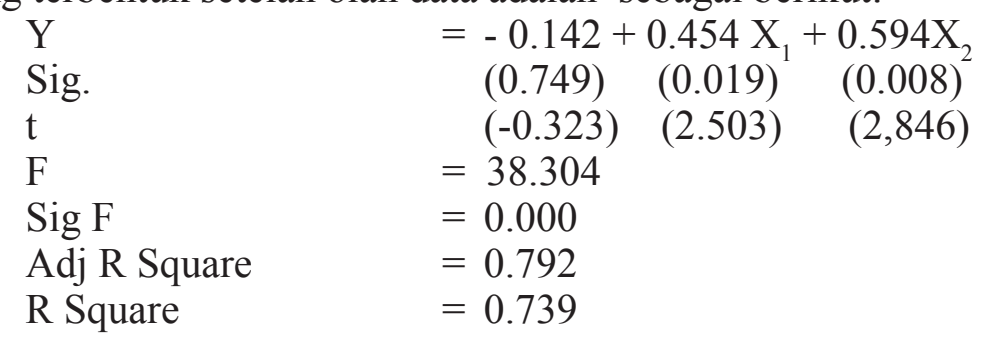


Dapat dijelaskan bahwa hasil dari uji signifikansi parsial menunjukkan bahwa nilai signifikansi variabel kreativitas $\left(\mathrm{X}_{1}\right)$ lebih kecil dari 5\%. Dengan demikian Ho akan ditolak karena $0.019<5 \%$. Hal ini memberikan makna bahwa kreativitas berpengaruh secara signifikan terhadap kualitas jiwa kewirausahaan. Variabel inovasi $\left(\mathrm{X}_{2}\right)$, Ho akan ditolak karena nilai signifikansi $0.008<5 \%$. Hal ini memberikan makna bahwa inovasi berpengaruh secara signifikan terhadap kualitas jiwa kewirausahaan. Uji signifkansi simultan, menunjukkan bahwa nilai signifikansi $\mathrm{F}<5 \%$. Dengan demikian Ho akan ditolak karena $0.000<5 \%$. Hal ini memberikan makna bahwa secara simultan kedua variabel bebas (kreativitas dan inovasi) berpengaruh secara signifikan terhadap variabel independen (kualitas jiwa kewirausahaan). Koefisien determinasi sebesar 0.792 pada Adjusted $R$ Squared memberikan makna bahwa sebesar $79.2 \%$ variasi kualitas jiwa kewirausahaan dapat dijelaskan oleh variasi kreativitas dan inovasi. Sedangkan sisanya sebesar 20.8\% dijelaskan oleh sebab-sebab lain di luar model.

\section{SIMPULAN}

Kualitas jiwa kewirausahaan pelaku usaha kecil di Kabupaten Bantul, tepatnya di Desa Argosari dipengaruhi secara parsial oleh variabel kreativitas. Hal ini dapat diukur dari hasil perhitungan analisis regresi yang menunjukkan nilai signifikansi sebesar $0.00<$ dari tingkat alpha yang digunakan (5\%). Variabel inovasi mempengaruhi secara parsial kualitas jiwa kewirausahaan perajin stagen inovasi. Kualitas jiwa kewirausahaan pelaku usaha kecil di Desa Argosari dipengaruhi secara simultan oleh faktor kreativitas dan inovasi, yang dapat diukur dari hasil perhitungan analisis regresi yang menunjukkan nilai signifikansi sebesar $0.00<$ dari tingkat alpha yang digunakan $(5 \%)$. Hasil memberikan makna bahwa perajin stagen inovasi memiliki kreativitas dan inovasi yang potensi untuk dikembangkan. Dengan demikian dapat memberikan gambaran yang lebih jelas pada pihak terkait untuk memberikan pembinaan dalam bentuk pelatihan bimbingan dan konsultasi usaha lebih diarahkan pada peningkatan kualitas jiwa kewirausahaan bagi para pelaku usaha kecil secara kontinyu dan terpadu. Pembinaan kualitas jiwa kewirausahaan secara khusus dapat lebih memfokuskan pada upaya peningkatan kreativitas dan inovasi para perajin stagen inovasi, serta adanya keinginan mengembangkan potensi yang ada dalam diri mereka secara optimal. Pembinaan dilakukan dengan mendorong para pelaku usaha kecil untuk dapat selalu meningkatkan kemampuan dalam menerapkan solusi kreatif terhadap masalah dan peluang untuk meningkatkan tingkat penghidupan di samping juga pembinaan yang berupa pemberian semangat bagi para pelaku usaha kecil untuk tidak gampang menyerah dari setiap kegagalan yang terjadi. Penelitian berikutnya sangat penting untuk memperhatikan faktor-faktor selain kreativitas dan inovasi yang tidak diikutkan dalam model penelitian ini yang diharapkan akan mempengaruhi kualitas jiwa kewirausahaan bagi para pelaku usaha kecil, antara lain faktor keberanian dalam pengambilan risiko, kepercayaan diri, pencarian peluang dan tuntutan terhadap kualitas dan hasil. 


\section{REFERENSI}

Affandi, Achmad Nur. 2011. Inovasi dan Daya Saing UMK. Makalah Seminar Membangun dan Meningkatkan daya Saing Nasional di Era Keterbukaan Ekonomi.

Anggraini, O., Retnaningdiah, D. dan Syakirin, B. 2006. Dinamika Kelompok Wanita Nelayan dalam Pengembangan Mikro Mitra Mina (Pemberdayaan Wanita Nelayan) di Kabupaten Gunung Kidul. Laporan Penelitian Hibah Bersaing.

Anggraini, O., Retnaningdiah, D. dan , Agus, M. 2007. Kajian Evaluatif Retrospektif Prospektif Pemberdayaan Wanita Nelayan dengan Mengoptimalkan Swamitra Mina Integratif Program Pemberdayaan Ekonomi Masyarakat Pesisir di DIY. Laporan Penelitian Hibah Bersaing.

Arikunto, Suharsimi. 1999. Prosedur Penelitian. Suatu Pendekatan Parametrik. Penerbit PT Melton Putra Jakarta.

Biro Pusat Statistik. 2008. Data Monografi Desa Argosari Kecamatan Sedayu Kabupaten Bantul.

Budiyuwono, Nugroho, 2007. Pengantar Statistik Ekonomi dan Perusahaan, UPP AMP YKPN, Yogyakarta.

Ghozali, Imam. 2009. Aplikasi Analisis Multivariate dengan Program SPSS. Cetakan IV. Badan Penerbit Universitas Diponegoro.

2009. Ekonometrika: Teori, Konsep, dan Aplikasi dengan SPSS 17. Badan Penerbit Universitas Diponegoro.

Hadjimonalis, Athanasius dan Keith Dickson. 2000. Inovation of SMEs in Cyprus Small Developing Countries. International Small Business Journal,18,4, pp 62-79.

Mahrinasari. 2003. Faktor-faktor yang Mempengaruhi Kualitas Jiwa Kewirausahaan Usaha Kecil. Jurnal Entrepreneurship, Vol. 1, No. 2, Mei, 101 - 113.

Umar, Husein. 2000. Riset Pemasaran dan Perilaku Konsumen. Penerbit PT Gramedia Pustaka Utama, Jakarta.

Yuniarto, Yudi A. 2002. Penilaian Kebutuhan Keterampilan dan Kemampuan Pemasar pada Usaha Kecil Sektor Industri di Kabupaten Sleman DIY. Jurnal Antisipas. Vol 6, No. 1

2004. Minat Mahasiswa Peserta Mata Kuliah Kewirausahaan di Jurusan Manajemen FE USD untuk Berwirausaha. Jurnal Antisipasi. Vol 8, No. 1.

Zimmerer, Thomas, Scarborough. 2008. Kewirausahaan dan Manajemen Usaha Kecil. Salemba Empat, Jakarta

Biro Pusat Statistik. 2008. Data Monografi Desa Argosari Kecamatan Sedayu Kabupaten Bantul. 
